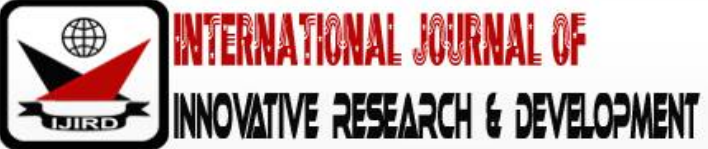

ISSN 2278 - 0211 (Online)

\section{Knowledge Management Capability, Demographics and Market Capitalizing Agility}

\author{
James Gathogo Kamau \\ Ph.D. Candidate, Department of Business Administration, \\ Kenya Methodist University, Kenya \\ Thomas Anyanje Senaji \\ Professor, Department of School of Business and Economics, \\ Kenya Methodist University, Kenya \\ Susan Chelang'at Nzioki \\ Lecturer, School of Business and Economics, \\ Kenva Methodist University, Kenva
}

\begin{abstract}
:
In this study, we examine the relationship between knowledge management capability and operational agility which is an important antecedent of competitive advantage in organisations. We first set out to determine the KM and organisational agility dispositions and then tested the relationship between the two in the Kenya banking sector using data from 172 respondents from commercial banks. Data was collected using structured questionnaires that were derived from literature and tested for validity and reliability prior to their use. We found that the relationship between knowledge management capability and market capitalizing agility was weak, negative and not significant at $\mathrm{p}<0.05$ but at $\mathrm{p} \varangle 0.1$ ( $\mathrm{r}$ $=-0.142, \mathrm{p} \varangle 0.063$ ). We also compared the mean scores of the two strategic capabilities across a set of demographic variables and found significant $(\mathrm{p}<0.01)$ variation in the two strategic capabilities across age, level education, and working experience. Further, a negative and significant relationship $(p<0.05)$ was found between both strategic capabilities and all the demographic variables. This one of first attempt to examine the relationship between KM capability (lower order capability) and market sensing agility (higher order capability) in a developing economy context. The findings imply that KM capability has not reached the threshold to positively influence the market capitalizing agility which is necessary for superior performance and that there are demographic characteristics that impact both knowledge management capability and market capitalizing agility. It is recommended that a further examination of KM capability and market capitalizing agility be conducted to determine what aspects lead to negative relationship between these two capabilities and between them and age, education and work experience.
\end{abstract}

Keywords: Knowledge management, market sensing agility, demographics

\section{Introduction}

Firms may gain competitive advantage through the initial position, managerial choices, resources and the firm's activities. The strongest competitive advantage is the strategy that cannot be imitated by other companies. For a firm to attain sustainable competitive advantage, it has to achieve a superior position, superior skills and superior resources within the industry (Kamukama, Ahiauzu \& Ntayi, 2011). This advantage is measured using indicators such as market coverage, market share, profitability and efficiency (Barney, 2014). From a dynamic capability view of the firm, any organisation should have strategic capabilities relevant to its chosen business and market. Two of these capacities are those related to knowledge resources (knowledge management) and those concerned with effectiveness in the market place (market capability) which are the focus of the present study.

\subsection{Knowledge Management}

Scholars have increasingly realized that knowledge management $(\mathrm{KM})$ capability may act as a complementary capability, fundamental to organizational agility, which is an essential ability to promote innovation of a firm (Kamhawi, 2012). Similarly, Senaji (2012, p. 1) asserts that "knowledge is a critical resource which if leveraged and exploited leads to superior performance of organizations"

Liao, Chuang and to (2011) define knowledge management capability (KMC) as the degree to which the firm mobilizes and deploys knowledge resources such as product knowledge, customer knowledge, and managerial knowledge across functional boundaries. This definition suggests that $\mathrm{KM}$ is a crucial strategic capability which is necessary for effective utilisation of knowledge resources for an organization's advantage. With new the economy increasingly becoming 
a more knowledge-based economy, knowledge is becoming the most important asset for organizational success among other assets such as capital, materials, machineries, and properties (Senaji \& Nyaboga, 2011; Senaji \& Kiseli, 2016).

\section{Market Capability}

Market capitalizing agility refers to a firm's ability to quickly respond to and capitalize on changes through continuously monitoring and quickly improving product/ service to address customers' needs (Cai, Huang, Liu, Davison \& Liang, 2013). This imperative is applicable to organisations of all types that have the necessity to satisfy stakeholders' demands. Specifically, the organisation need the necessary knowledge of the market place which includes the customer needs and the competitors' moves which are in state of continues flux.

Since knowledge management is essentially a people process with technology as an enable of those processes, the characteristic of the people in organisations has important implications for the success of KM. It is also noted that the success of KM may depend on people's motivation and learning. This being the case, it is scarcely documented in empirical literature how demographic variables particularly age, level of education and working experience in an organisation relates with strategic capabilities.

Currently, commercial banks operating in Kenya are experiencing a faster pace of change hence the need for agility - the disposition of being nimble, flexible and practice - in the face of fast changing business environment. The industry is now characterized by customers' sophistication, strict regulation and supervision, technology advancement, liberalization of banking license leading to rapid internationalization. In order to survive, commercial banks need to have the best strategic capabilities and organizational agility is required. Both KMC and MCA have been found in previous studies to be related with superior performance of organisation and with each other with KMC being a first (lower) order capability MCA is a higher second (higher) order capability. Tis being the case it is of interest to ascertain the disposition of organisations along these two capabilities with the aim of improving it. However, empirical literature on the relationship between strategic capabilities and competitive advantage remains scarce and those that exist indicate knowledge gaps.

This research thus attempted to fill this gap by examining the relationship between the two strategic capabilities and their relationships with demographic variables - age, level of education and working experience of employees in a developing country context. This context was important because it is characterised by less developed financial markets which leads to inadequate access to financial services that potentially negate socio-economic development efforts. In the present study, we set out to examine the disposition of banks with regard to KMC and MCA and tested the relationship between KMC and $\mathrm{MCA}$, and how these two strategic capabilities varied across demographic characteristics (age, level of education and work experience) of respondents. We also tested the relationship between the strategic capabilities and the employee characteristics.

\section{Theory and Hypothesis}

This study was anchored on dynamic capability Theory.The dynamic capability theory proposed by Teece et al. (1997) suggests that the success of a firm relies on its ability to integrate, build, and reconfigure internal and external competencies to achieve new forms of competitive advantage. Scholars further proposed that the view of a hierarchy of capabilities and the view of capability embeddedness could constitute the basic views of the dynamic capability perspective where various kinds of resources and specialized knowledge could be combined and integrated to generate lower-order capabilities. These lower-order capabilities are combined to generate higher-order capabilities, which can enhance the performance or competitive advantage of organizations (Grewal \& Slotegraaf, 2007).

Some researchers posit that the lower-order capabilities contain operational routines and higher-order ones contain dynamic capabilities. In the existing literature, organizational agility has been treated as one type of dynamic capability, which refers to a higher-order capability (Dunlop-Hinkler et al, 2011). It is widely acknowledged that as a higher-order capability, organizational agility not only can enhance performance directly but also it can be developed as a consequence of other capabilities, such as Knowledge management capability and IT capability (Sambamurthy et al, 2003).

The theory argues that organizational agility not only enhances performance directly but also it can be developed as a consequence of other capabilities, such as Knowledge management capability and IT capability. It therefore supports the role of KMC MCA in an organization's performance. The theory also predicts a positive relationship between organizational agility and competitive advantage; and also, between KMC (lower level capability and market capitalizing agility (higher level strategic capability).

Knowledge management promotes organizational agility mainly through improving innovative response (TrinhPhuong, Molla \& Peszynski, 2012). Specifically, with a favorable level of knowledge management, tacit knowledge processed by individual can be converted to explicit knowledge in order to transfer it for use in improving comprehension of the business environment and creation of suitable. products and services to serve the evolving needs of customers.

Liu, Song and Cai (2014) established the relationship between knowledge management capability and firm performance as well as the mediating role of organizational agility. Based on the dynamic capabilities' perspective, this study explored how $\mathrm{KMC}$ (i.e., exploration $\mathrm{KMC}$ and exploitation $\mathrm{KMC}$ ) affected firm performance through the mediating role of operational adjustment agility and market capitalizing agility. Survey data from 211 firms indicated that both operational adjustment agility and market capitalizing agility can fully mediate the influence of $\mathrm{KMC}$ on firm performance. Among the indicators of knowledge management capability are staff recruitment systems favor competent recruits, research and development to enhance knowledge in an organisation, mechanisms to enhance knowledge on customer needs, seeking knowledge on customer preferences, and presence of knowledge sharing to enhance knowledge on governance of the firm.

Similarly, the practices of market capitalizing agility include continuously conducting market surveys to establish the trends in the market, monitoring the market trends and adjusting accordingly, improving services according to change 
of customers' preferences, quickly improving products according to change of customers' preferences, and the use of modeling to predict the market trends in the future.

Consistent with the reviewed literature and the aim of this study we hypothesized as follows:

In order to determine the adequacy of extent of development of the KMC and MCA among commercial banks we hypothesized that:

- $\mathrm{H}_{1}$ : Knowledge management capability and market capitalizing agility are well developed in commercial banks in Kenya

We also aimed to examine the relationship between KMC and MCA since existing empirical literature suggests that $\mathrm{KMC}$ is an antecedent of MCA with the latter being a lower level strategic capability with the latter being a higher-level capability. We therefore hypothesized that:

- $\mathrm{H}_{2}$ :Knowledge Management capability is an antecedent of market capitalizing agility such that the more developed the knowledge management capability is the greater will be the market capitalizingagility among commercial banks in Kenya

Lastly, since age, education and experience has been shown to have a relationship with learning and acquisition of knowledge to execute various tasks in an organisation, our interest was to understand whether the rating of these two capabilities (KMC and MCA) significantly varied across these demographic variables. In this regard, our third hypothesis was as follows:

- $\mathrm{H}_{3}$ : Knowledge management capability and market capitalizing agility are perceived the same across demographic variables, namely age, education and work experience

\section{Methodology}

\subsection{Research Design}

A cross-sectional survey design was used to examine the relationship between knowledge management capability and market capitalizing agility. The design was chosen because our aim was to study the phenomena at one point in time without incorporating temporal aspects of the phenomena. The study was conducted of a period of two months across 39 banks in Kenya with multiple respondents from each bank to minimize single respondent bias that would arise if only one respondent per bank was used.

\subsection{Target Population}

The target population comprised head of human resource department, operations department, finance department, research and development department, information technology department, head of customer care department; and sales and marketing department form each of the 39 banks; a total of 273 managers. This category of respondents was targeted because they are conversant with strategy and operations in their respective banks.

\subsection{Data Collection Instruments}

Data was collected using structured questionnaires for each of the study variables. This type of questionnaires is more appropriate because it enables consistency in questions asked and the collected data is easy to analyze. The questionnaires required the respondents to provide their independent views on the study phenomena without the influence of the researcher. Each variable was operationalized using multiple items (KMC: 9 items; MCA: 7 items) which were anchored on a 5-point Likert scale type scale. Likert scale is an interval scale that specifically uses five anchors of strongly disagree, disagree, neutral, agree and strongly agree. This scale is suitable for measuring perception, attitude, values and behavior (Upagade \& Shende, 2012) and was suitable because we set out to measure the perceptions and attitudes of respondents on KM capability and market sensing capability. The structured questionnaire that was used enabled the researcher to collect first-hand information over a short period of time.Beside the questions/ statements on the two strategic capability variables (KMC and MCA), data was also collected on the age, level of education and work experience of the respondents.

\subsection{Measures of Variables}

The two variables in this study were KM Capability (KMC) and Market Capitalizing Agility (MCA). Some of the measures of KMC were "whether recruitment systems favored competent recruits", "extent of deployment of employees to units is based on competence", "whether research and development is conducted enhance the firm's knowledge on service", and the "extent to which mechanisms had been put in place to enhance knowledge on customer preferences". Similarly, MCA was measured by items which included the respondents' assessment of extent to which the bank continuously conducted market surveys to establish the trends in the market, how the bank monitored the market status and adjusted accordingly; and how continuously the bank communicated with customers to understand their preferences. The complete measures of variables are presented in Table 1 with nine and seven items for KMC and MCA respectively. 


\begin{tabular}{|c|}
\hline Knowledge Management Capability \\
\hline In my organization, the recruitment systems favor competent recruits \\
\hline In my organization, the deployment of employees to units is based on competence \\
\hline In my organization, research and development is conducted to enhance the firm's knowledge on products \\
\hline In my organization, research and development is conducted enhance the firm's knowledge on services \\
\hline In my organization, research and development is conducted to enhance the firm's knowledge on services \\
\hline In my organization, mechanisms have been put in place to enhance knowledge on customer needs \\
\hline In my organization, mechanisms have been put in place to enhance knowledge on customer preferences \\
\hline In my organization, mechanisms have been put in place to enhance knowledge on customer buying behavior \\
\hline In my organization, knowledge sharing to enhance knowledge on governance of the firm is practiced \\
\hline Market Capitalizing Agility \\
\hline My bank continuously conducts market surveys to establish the trends in the market \\
\hline My bank continuously monitors the market trends and adjusting accordingly \\
\hline My bank continuously monitors the market status and adjusting accordingly \\
\hline My bank quickly improves services according to change of customers' preferences \\
\hline My bank quickly improves products according to change of customers' preferences \\
\hline My bank continuous communicates with customers to understand their preferences \\
\hline My bank uses modeling to predict the market trends in the future \\
\hline
\end{tabular}

Table 1: Measure of Variables

\subsection{Reliability of Instruments}

According to Cronbach (1951) and Cooper and Schindler (2009), reliability is the proportion of variance attributable to the true measurement of a variable and consistency of such measurement over time. It is concerned with the internal properties of a measure and the random error in the data and ranges from nil (0) to perfection (1). Cooper and Schindler (2009); Cronbach (1984) noted that a Cronbach Alpha Coefficient of 0.7 and above was acceptable because random error always exist regardless of the procedure used in the study. Christensen, Johnson, Turner and Christensen (2011) noted that the threshold for Cronbach's Alpha varies among disciplines and the nature of the study. They argued that a value above 0.7 is generally accepted while a value of 0.6 is normally accepted for completely new instruments.

The measurement scale for reliability was tested using Cronbach alpha coefficient for every independent variable and for an alpha $(\alpha)$ of 0.7 and above the instrument was be interpreted as reliable (Cronbach, 1951). A high reliability estimate should be as close to 1 as possible. The study adopted a Cronbach alpha of 0.7 which is accepted for instruments that are not completely new. The testing for reliability was done by administering the questionnaire to 12 respondents from two randomly selected commercial banks which were not included in the main survey. The pilot test results for all the variables are presented in Table 2 and discussed thereafter.

\begin{tabular}{|c|c|c|c|}
\hline Variable & Cronbach's Alpha & Number of Items & Remark \\
\hline Knowledge Management Capability & 0.717 & 9 & Reliable \\
\hline Market capitalizing agility MCA) & 0.857 & 7 & Reliable \\
\hline
\end{tabular}

Table 2: Reliability Test

As see in Table 4.2, seven items were used to measure market capitalizing agility (MCA); their Cronbach alpha was 0.857. Similarly, the Cronbach alpha for the nine9 questions which knowledge management capability (KMC)market capitalizing agility was 0.717 which was above the threshold of 0.7 implying that the 9 measures were consistency in measurement of KMC. From these results all items in the original instrument for this variable were retained upon reliability test.

\subsection{Data Collection Procedure}

The questionnaires were self-administered through the drop-and-pick later method where the questionnaires were distributed and left for the respondents to respond at their convenience in the absence. In this way, we did not influence the response from the studied units. In order to increase the response rate,we made follow up calls to the respondents. Pre-notification of respondents of the study and voluntary participation by respondents was requested in advance. We assured the respondents of confidentiality and anonymity of the responses. In order to know the bank of the respondent, the questionnaire was coded, prior to distribution to respondents to allow us know the bank from which a response emanated. For the distribution of the questionnaires, we trained three research assistants for half a day and assigned 13 banks to distribute and collected filled up questionnaires. Further data on three demographic variables, namely age, level of education and work experience were also collected and the two strategic capabilities (KMC and MCA) compared across them.

\subsection{Data Analysis}

One the filled-up questionnaire was received; they were checked for completeness and incomplete ones discarded. The complete once was coded and the data entered into the SPSS version 22 program in a computer. Frequency tables of the responses were generated for the collected on the demographic variable - age, level of education and working 
experience - and the c data analysed to determine the disposition of the banks regarding KM capability and market capitalization capability. Means, standard deviations of the responses on the two strategic capability variables (KMC and $\mathrm{MCA}$ ) and the correlation between them calculated and the results interpreted and discussed. We also compared aggregate means of KMC and MCA across age, level of dedication and working experience to ascertain whether they were homogeneous and the relationship between the strategic capabilities and the three demographic variables.

\section{Results and Discussion}

\subsection{Response Rate}

The researcher administered a total of 273 questionnaires to respondents comprising of head of human resource department, operations department, finance department, research and development department, information technology department, head of customer care department and sales and marketing department. Respondents were drawn from 39 operational commercial banks licensed by CBKand operating in Kenya.

A total of 172 questionnaires were dully filled and returned which represented a response rate of $63 \%$. The results are shown in Table 4.1 below. This response rate was adequate since according to Babin (2010), a response rate of $50 \%$ is acceptable for analyzing and publishing while $60 \%$ is good and above $70 \%$ is considered to be very good. The high response rate is attributed to the data collection procedures that were used in the study. The data collection procedures included use of competent research assistants, pre-notification of respondents and voluntary participation by respondents; drop and pick of questionnaires to allow for ample time to fill; assurance of confidentiality and anonymity and follow up calls to clarify queries from the respondents.

\subsection{Demographic Characteristics}

This section contains study findings on respondents' demographic characteristics comprising of age, level of education and experience. According to Smith (2015), establishing the demographic characteristics of the respondents does not affect the relationship between the variables of the study. It however describes the population under investigation and allows the comparison of the results on variables across these variables to determine whether the results significantly vary with demographic variables. In this study we collected data on age, level of education and work experience; the results are presented on Table 3.

\begin{tabular}{|c|c|c|c|}
\hline Variable & Indicator & Frequency & Percentage \\
\hline Age Bracket & $21-30$ Years & 12 & 7 \\
\hline & $31-40$ Years & 24 & 14 \\
\hline & $41-50$ Years & 68 & 40 \\
\hline & Over 50 Years & 68 & 40 \\
\hline & Total & 172 & 100 \\
\hline Level of Formal Education & Tertiary & 20 & 11.6 \\
\hline & University & 152 & 88.4 \\
\hline & Total & 172 & 100 \\
\hline & Less than 3 Years & 12 & 7 \\
\hline Work Experience & 3 to 5 Years & 64 & 27.9 \\
\hline & 6 to 10 Years & 48 & 27.9 \\
\hline & Over 10 Years & 48 & 100 \\
\hline
\end{tabular}

Table 3: Age, Level of Education and Working Experience

\subsubsection{Respondents Age}

The study results (Table 3 ) suggest that majority of the respondents $(n=68,40 \%)$ were of age bracket of 50 years and above while those aged between 41 and 50 years were also $40 \%(n=68)$. Similarly, 14\% were of age bracket 31 and 40 years $(n=24)$ while only 7\% $(n=12)$ of respondents aged between 21 and 30 years. The results indicate that most of the respondents occupying the positions of head of human resource department, operations department, finance department, research and development department, information technology department, head of customer care department and sales and marketing department in commercial banks in Kenya are of age 41 years and above.

\subsubsection{Level of Formal Education}

According to the results, a majority, $88.4 \%(\mathrm{n}=152)$ had acquired university level of education while $11.6 \%(\mathrm{n}=$ 20) had acquired tertiary level of education. It was found that none of the respondent had secondary school level of education. This implies that all respondents included in the study were educated and would understand the contents of the questionnaires and respond to them accordingly.

\subsubsection{Respondents Experience}

According to the results in Table 3, 27.9\% $(\mathrm{n}=48)$ of respondents had worked in the bank for more than 10 years and also for between 6 and 10 years $(n=48,27.9 \%)$. Those who had worked in the bank between 3 and $5(n=64$, $37.2 \%$ were he majority and Further, only $7 \%(\mathrm{n}=12)$ of respondents had worked in the bank for less than three years. The results imply that majority of the respondents had worked in the bank for more six years which was a long enough 
time for them to provide accurate and important information for the study. Specifically, the majority of the respondents ( $\mathrm{n}$ =96; $55.8 \%)$ had over five years' experience while only $7 \%(n=12)$ had less than three years' experience. The category that had the most respondents was 3 to 5 years which had $37.2 \%(n=64)$ of the respondents

\subsection{Comparison of $\mathrm{KMC}$ and $\mathrm{MCA}$ across Age, Education and Experience}

We also compared means across the demographic variables (age, level of education and working experience) and examined the relationship between these variables (age, level of education and working experience) with both KMC and MCA.

\subsubsection{Comparison of means of KM Capability across Age, Level of Education and Working Experience}

The results of the comparison of means of KMC and MCA across age, level of education and work experience are presented in Table 4.

\begin{tabular}{|c|c|c|c|c|c|c|c|}
\hline \multicolumn{8}{|c|}{ ANOVA Table } \\
\hline & & & $\begin{array}{l}\text { Sum of } \\
\text { Squares }\end{array}$ & $\mathrm{df}$ & $\begin{array}{l}\text { Mean } \\
\text { Square }\end{array}$ & $\mathrm{F}$ & Sig. \\
\hline \multirow{3}{*}{$\begin{array}{l}\text { Age* Knowledge } \\
\text { Management } \\
\text { Capability }\end{array}$} & $\begin{array}{l}\text { Between } \\
\text { Groups }\end{array}$ & (Combined) & 61.172 & 17 & 3.598 & 7.243 & .000 \\
\hline & \multirow{2}{*}{\multicolumn{2}{|c|}{$\begin{array}{c}\text { Within Groups } \\
\text { Total }\end{array}$}} & 76.503 & 154 & .497 & & \\
\hline & & & 137.674 & 171 & & & \\
\hline \multirow{3}{*}{$\begin{array}{l}\text { Education* } \\
\text { Knowledge } \\
\text { Management } \\
\text { Capability }\end{array}$} & $\begin{array}{l}\text { Between } \\
\text { Groups }\end{array}$ & (Combined) & 8.093 & 17 & .476 & 7.652 & .000 \\
\hline & \multicolumn{2}{|c|}{ Within Groups } & 9.581 & 154 & .062 & & \\
\hline & \multicolumn{2}{|c|}{ Total } & 17.674 & 171 & & & \\
\hline \multirow{3}{*}{$\begin{array}{l}\text { Working experience } \\
\text { * Knowledge } \\
\text { Management } \\
\text { Capability }\end{array}$} & $\begin{array}{c}\text { Between } \\
\text { Groups }\end{array}$ & (Combined) & 82.974 & 17 & 4.881 & 11.099 & .000 \\
\hline & \multirow{2}{*}{\multicolumn{2}{|c|}{$\begin{array}{c}\text { Within Groups } \\
\text { Total }\end{array}$}} & 67.724 & 154 & .440 & & \\
\hline & & & 150.698 & 171 & & & \\
\hline
\end{tabular}

Table 4: Age Education Experience

* Knowledge Management Capability

As see from the results (Table 4), there was a significant difference ( $p<0.001$ for all variables) in the rating of the KMC across age, education and experience in the bank. The most significant difference in the means was across work experience $(\mathrm{F}=11.099, \mathrm{p}<0.001)$ followed by level of education $(\mathrm{F}=7.652, \mathrm{p}<0.001)$ and lastly age of respondent $(\mathrm{F}=7.243, \mathrm{p}<$ $0.001)$.

\subsubsection{Comparison of Means of Market Capitalizing Agility across Age, Level of Education and Working Experience}

In Table 5, the results of the comparison of the mean responses on MCA across age, level of education and working experience of respondents (bank managers) are presented

\begin{tabular}{|c|c|c|c|c|c|c|c|}
\hline \multicolumn{8}{|c|}{ ANOVA Table } \\
\hline & & & $\begin{array}{l}\text { Sum of } \\
\text { Squares }\end{array}$ & $\mathrm{df}$ & $\begin{array}{l}\text { Mean } \\
\text { Square }\end{array}$ & $\mathrm{F}$ & Sig. \\
\hline \multirow[t]{3}{*}{$\begin{array}{c}\text { Age * Market } \\
\text { Capitalizing Agility }\end{array}$} & $\begin{array}{c}\text { Between } \\
\text { Groups }\end{array}$ & (Combined) & 38.348 & 14 & 2.739 & 4.330 & .000 \\
\hline & \multicolumn{2}{|c|}{ Within Groups } & 99.327 & 157 & .633 & & \\
\hline & \multicolumn{2}{|c|}{ Total } & 137.674 & 171 & & & \\
\hline \multirow[t]{3}{*}{$\begin{array}{l}\text { Education* Market } \\
\text { Capitalizing Agility }\end{array}$} & $\begin{array}{c}\text { Between } \\
\text { Groups }\end{array}$ & (Combined) & 6.335 & 14 & .452 & 6.265 & .000 \\
\hline & \multicolumn{2}{|c|}{ Within Groups } & 11.340 & 157 & .072 & & \\
\hline & \multicolumn{2}{|c|}{ Total } & 17.674 & 171 & & & \\
\hline \multirow[t]{3}{*}{$\begin{array}{l}\text { Experience * Market } \\
\text { Capitalizing Agility }\end{array}$} & $\begin{array}{c}\text { Between } \\
\text { Groups }\end{array}$ & (Combined) & 26.972 & 14 & 1.927 & 2.445 & .004 \\
\hline & \multicolumn{2}{|c|}{ Within Groups } & 123.726 & 157 & .788 & & \\
\hline & \multicolumn{2}{|c|}{ Total } & 150.698 & 171 & & & \\
\hline
\end{tabular}

Table 5: Age Education Experience

* Market Capitalizing Agility

As see from the results (Table 6), there was a significant difference ( $p<0.001$ for all variables) in the rating of the MCA across age, education and experience in the bank. The biggest difference in means was across education level $(\mathrm{F}=$ 
6.265, $p<0.001)$ while the least was across working experience $(F=2.145, p<0.004)$ in the bank; al the differences were significant at both $1 \%$ significance level $(\mathrm{p}<0.01)$.

\subsection{Relationship between KMC and MCA with Age, Education and Experience}

Arising from the results of the comparison of KMC and MCA means across the demographic variables (age, level of education and working experience in the bank) we investigated the relationship between them and the demographics: age, level of education and working experience; the result is presented in Table 6

\begin{tabular}{|c|c|c|c|c|}
\hline & \multicolumn{2}{|c|}{ Correlations } & & \\
\hline & Age & 1 & 2 & 3 \\
\hline 1 & Education & $.696^{* *}$ & & \\
\hline 2 & & $<0.001$ & & \\
\hline & Experience & $.865^{* *}$ & $.530^{* *}$ & \\
\hline 3 & & $<0.001$ & $<0.001$ & \\
\hline & & $-.314^{* *}$ & $-.170^{*}$ & $-.206^{* *}$ \\
\hline 4 & Market Capitalizing Agility & $<0.001$ & 0.026 & 0.007 \\
\hline & & $-.370^{* *}$ & -0.141 & $-.498^{* *}$ \\
\hline 5 & Knowledge Management Capability & $<0.001$ & 0.066 & $<0.001$ \\
\hline & & 172 & 172 & 172 \\
\hline & & & \\
\hline
\end{tabular}

Table 6: Relationship between Demographics (Age, Education and Experience) and Strategic Capabilities

As shown from the results (Table 6) Age was negatively and significantly related with both MCA $(r=-0.314, p$ $<<0.001)$ and KMC $(r=-0.370, p<<0.001)$ the relationships are significant at $5 \%(p<0.005)$ significance level. Further, education level and experience were also negatively related with MCA (education: $r=-0.170, p=0.026<0.05$; work experience: $r=-0.206, p=0.007<0.05)$; similarly, KMC was negatively and significantly related with level of education $(r$ $=0.141, \mathrm{p}=0.066<0.01, \mathrm{p}>0.05)$ at $10 \%$ significance level; and with experience at $5 \%$ significance level $(\mathrm{r}=-0.498, \mathrm{p}<$ 0.001). This resultsuggests that the higher the age, education level, work and experience the lower would be the rating on the state of both KMC and MCA. The results in also suggest the existence of a negative relationship between KMC and MCA though the relationship is not significant at $\mathrm{p}<0.05$ but at $\mathrm{p}<0.1(\mathrm{r}=-0.142, \mathrm{p}=0.063<0.1)$.

\subsection{Knowledge Management Capability}

The objective this study was to establish the relationship between knowledge management capability and market capitalizing agility in the banking sector in Kenya. We first examined the KM practices in the banks followed by the determination of the relationship between KMC and MCA. Two KMpractices (on the job training and frequency of training) were studied. The following subsection presents concerning how respondents regarded the various issues under KMC variable, namely job training, frequency of training and knowledge management practices. While the results on job training and training frequency are presented in Table 6, those for KM practices are shown on Table 7. Data on the extent of agreement with regard to job training, and adoption of KM practices in the banks were anchored on a fivepointLikertscale of 1 to 5 where $1=$ No extent, $2=$ Little extent, $3=$ Moderate Extent, $4=$ Large extent and $5=$ Very large extent. Meanwhile the data on frequency of training were reported as twice, thrice or more than three times in a year.

\begin{tabular}{|c|c|c|c|}
\hline Variable & Ranking & Frequency (n) & Percent (\%) \\
\hline Extent of on the Job Training & Moderate extent & 74 & 43 \\
\hline & Largeextent & 59 & 34.3 \\
\hline & Very largeextent & 39 & 22.7 \\
\hline & Total & 172 & 100 \\
\hline Frequency of Training & Twice Per Year & 50 & 29 \\
\hline & Three times per Year & 55 & 32 \\
\hline & More than three times per Year & 67 & 39 \\
\hline & Total & 172 & 100 \\
\hline
\end{tabular}

Table 7: Extent of on the Job Training and Frequency of Training

\subsubsection{Job Training}

First, the respondents were asked to indicate the extent to which the bank provided on the job training to improve employee's knowledge. According to the results (Table 7), majority of the respondent ( $\mathrm{n}=74,43 \%)$ agreed, to moderate extent, that their employers were provided on- job - training to improve employee's knowledge. Those who agreed to a large extent $34.3 \%(n=59)$, while $22.7 \%(n=39)$ agreed to a very large extent. The results imply that most of the commercial banks provided employees on job training to a moderate extent to improve employee's knowledge. 


\subsubsection{Frequency of Training}

In addition, to the statement regarding the frequency with which the banks trained employees to improve their skills, 39\% ( $n=67)$ of respondent indicated that their organizations trained employees for more than three times per year while 32\% ( $n=55)$ indicated that training was done three times per year. On the other hand, $29 \%(n=50)$ indicated that training in the organization happened twice per year. The results suggest that most of the organizations conducted employee training more than three times per year.

\subsubsection{Adoption of Knowledge Management Practices}

Further, results of analysis of data from respondents on the extent of agreement with statements on knowledge management practices are presented in Table.7.

\begin{tabular}{|c|c|c|}
\hline Statement & Mean & SD \\
\hline In my organization, the recruitment systems favor competent recruits & 4.45 & 0.78 \\
\hline In my organization, the deployment of employees to units is based on \\
competence & 4.38 & 1.07 \\
\hline $\begin{array}{c}\text { In my organization, research and development is conducted to enhance } \\
\text { the firm's knowledge on products }\end{array}$ & 4.19 & 1.08 \\
\hline $\begin{array}{c}\text { In my organization, research and development is conducted enhance the } \\
\text { firm's knowledge on services }\end{array}$ & 4.15 & 1.05 \\
\hline $\begin{array}{c}\text { In my organization, research and development is conducted to enhance } \\
\text { the firm's knowledge on services }\end{array}$ & 4.15 & 0.92 \\
\hline $\begin{array}{c}\text { In my organization, mechanisms have been put in place to enhance } \\
\text { knowledge on customer needs }\end{array}$ & 3.91 & 0.85 \\
\hline $\begin{array}{c}\text { In my organization, mechanisms have been put in place to enhance } \\
\text { knowledge on customer preferences }\end{array}$ & 3.90 & 0.73 \\
\hline $\begin{array}{c}\text { In my organization, mechanisms have been put in place to enhance } \\
\text { knowledge on customer buying behavior }\end{array}$ & 3.62 & 1.06 \\
\hline $\begin{array}{c}\text { In my organization, Knowledge sharing to enhance knowledge on } \\
\text { governance of the firm is practiced }\end{array}$ & 4.30 & 1.08 \\
\hline Average & 4.12 & 0.96 \\
\hline
\end{tabular}

Table 8: Extent of Adoption of Knowledge Management Practices

On average (see Table 8) there was to a large extent agreement $(\mathrm{M}>4.00$; Large extent: $\mathrm{M}=4.00)$ that $\mathrm{KM}$ practices had been adopted in the studied banks with the recruitment systems favoring competent recruits $(\mathrm{M}=4.45, \mathrm{SD}=$ $0.48)$, and that the deployment of employees to units was based on competence $(\mathrm{M}=4.38,=1.07)$. Further, research and development were being conducted to enhance the firm's knowledge on products ( $M=4.19, S D=1.08)$, and that research and development is conducted to enhance the firm's knowledge on services ( $\mathrm{M}=4.15, \mathrm{SD}=1.05)$. The least prevent $\mathrm{KM}$ practice was thatwhich was about "mechanisms have been put in place to enhance knowledge on customer buying behavior" ( $\mathrm{M}=3.62, \mathrm{SD}=1.06)$. These findingsconcur with Teece et al. (1997) who suggested that the success of a firm relies on its ability to integrate, build, and reconfigure internal and external competencies to achieve new forms of competitive advantage. The implication is that the organisations were making sufficient effort in KM capability activities.

\subsubsection{Market Capitalizing Agility}

We also analysed data on market capitalizing agility. Similar to that data on KMC, this data was anchored o a fivepoint Likert scale as earlier described the results are found in Table 8.

\begin{tabular}{|c|c|c|}
\hline Statement & Mean & SD \\
\hline $\begin{array}{c}\text { My bank continuously conducts market surveys to establish the } \\
\text { trends in the market }\end{array}$ & 3.97 & 1.32 \\
\hline $\begin{array}{c}\text { My bank continuously monitors the market trends and adjusting } \\
\text { accordingly }\end{array}$ & 3.45 & 1.51 \\
\hline $\begin{array}{c}\text { My bank continuously monitors the market status and adjusting } \\
\text { accordingly }\end{array}$ & 4.10 & 1.33 \\
\hline $\begin{array}{c}\text { My bank quickly improves services according to change of } \\
\text { customers' preferences }\end{array}$ & 3.34 & 1.37 \\
\hline $\begin{array}{c}\text { My bank quickly improves products according to change of } \\
\text { customers' preferences }\end{array}$ & 3.49 & 1.15 \\
\hline $\begin{array}{c}\text { My bank continuous communicates with customers to } \\
\text { understand their preferences }\end{array}$ & 4.13 & 0.76 \\
\hline My bank uses modeling to predict the market trends in the future & 3.55 & 1.20 \\
\hline Average & 3.72 & 1.23 \\
\hline
\end{tabular}

Table 9: Extent of Implementation of Market Capitalizing Agility 
According to the results, the most prominently practiced aspects of market capitalizing agility were continuous communicates with customers to understand their preferences $(\mathrm{M}=4.13, \mathrm{SD}=0.76)$, and continuously monitoring the market status and adjusting accordingly $(\mathrm{M}=4.10, \mathrm{SD}=1.33)$. However, there were wide variations in the latter $(\mathrm{SD}=$ 1.33) compared to those in former $(\mathrm{SD}=0.76)$. On average, there was insufficient market capitalizing agility $(\mathrm{M}=3.72, \mathrm{SD}$ $=1.23$ ) in the organisations and that the responses were widely varied ( $\mathrm{SD}=1.23$ ) indicating that either the respondents had different views about the extent of MCA or they had different understanding of what it (MCA) is.

\subsection{Relationship between Demographics Variables and Strategic Capability}

Since, there was significant difference in means of the strategic capabilities across the respondents' three demographic variables (age, level of education and working experience), correlation analysis was used to examine the relationship between demographics and the two strategic capabilities (KMC and MCA). The correlation results are presented on Table 9

\begin{tabular}{|l|l|l|l|l|l|l|}
\hline & Correlations & & & & & \\
\hline & & 1 & 2 & 3 & 4 & 5 \\
\hline 1 & Age & & & & & \\
\hline 2 & Education & $.696^{* *}$ & & & & \\
\hline & & $<0.001$ & & & & \\
\hline 3 & Experience & $.865^{* *}$ & $.530^{* *}$ & & & \\
\hline & & $<0.001$ & $<0.001$ & & & \\
\hline 4 & Market Capitalizing Agility & $-.314^{* *}$ & $-.170^{*}$ & $-.206^{* *}$ & & \\
\hline & & $<0.001$ & 0.026 & 0.007 & & \\
\hline 5 & $\begin{array}{l}\text { Knowledge Management } \\
\text { Capability }\end{array}$ & $-.370^{* *}$ & -0.141 & $-.498^{* *}$ & -0.142 & \\
\hline & & $<0.001$ & 0.066 & $<0.001$ & 0.063 & \\
\hline & & 172 & 172 & 172 & 172 & 172 \\
\hline
\end{tabular}

Table 10: Relationship between Demographics Variables and Strategic Capability

** Correlation Is Significant at the 0.01 Level (2-Tailed)

* Correlation Is Significant at the 0.05 Level (2-Tailed)

The results (Table 9) imply that both KMcapability and market capitalizing agility are negativelyand significantly related with age, level of education and working experience of the managers in the banks since all the correlation coefficients are negative and significant at $\mathrm{p}<0.05$ except for that between KMC and level of education $(\mathrm{r}=-0.141, \mathrm{p}=$ $0.066>0.05)$ which was significant at $\mathrm{p}<0.1(10 \%$ significance level). Further, the relationship between MCA and KMC was negative $(r=0.142, p=0.063)$ and only significant at $10 \%$ level of significance $(p<0.1)$. These findings constitute a new insight into the relationship between demographic variables and strategic capability

\section{Conclusion}

We set out to test three hypotheses. The first hypothesis was that:

- $\mathrm{H}_{1}$ : Knowledge management capability and market capitalizing agility are well developed in commercial banks in Kenya

According to the findings, the respondents agreed to large extent that $\mathrm{KM}$ practices were, to large extent (M > 4.00) present in the commercial banks in Kenya. We therefore accept this hypothesis. Conversely, market capitalizing agility was found to be moderate $(\mathrm{M}=3.72<4.00, \mathrm{SD}=1.23$ ) leading to the partial rejection of the hypothesis and concluding that market capitalizing agility was not well developed among the commercial banks

The second hypothesis that was test was:

- $\mathrm{H}_{2}$ :Knowledge Management capability is an antecedent of market capitalizing agility such that the more developed the knowledge management capability is the greater will be the market capitalizing agility among commercial banks in Kenya

Based on the 5\% significance level this hypothesis is rejected. Further, since the relationship between knowledge management capability and market capitalizing capability was found to be negative $(r=-0.142, p=0.066)$ and significant at $\mathrm{p}<0.063$, we could not conclude that KMC was an antecedent of MCA because this finding suggest that the more the $\mathrm{KMC}$ the less would be MCA which is inconsistent the previous studies

Lastly, we tested the third hypotheses which was:

- $\mathrm{H}_{3}$ : Knowledge management capability and market capitalizing agility are perceived the same across demographic variables, namely age, education and work experience

The findings of this study were that, there was a very statistically significant difference $(p<0.001)$ in the perception of both KMC and MCA across age, level of education and working experience. Consequently, $\mathrm{H}_{3}$ was rejected and a conclusion reached that KMC and MCA are perceived differently across age, level of education and working experience among commercial banks in Kenya in addition, age, level education and working experience were found to have negative and significant relation with $\mathrm{Km}$ capability and market capitalizing agility

Though these findings provide important insights into the level of development of strategic capabilities and how they related with the employees' demographic variables, the study has some limitations to generalizability. First, the study was 
conducted in one sector, and secondly, a narrow scope of organisational strategic capability (KM capability and market capitalizing capability) were considered.

\section{Implications}

The findings of this study have important implications. First, the practitioners can use these findings to improve their disposition on KMC and MCA because the extent of the practice of each of indicators (measures) of these two capabilities are presented in the descriptive results. Secondly, the findings suggest that KMC may not be an antecedent of MCA, which contradicts previous findings. As a consequence, it is necessary to test this relationship in other settings to determine ascertain this finding. Further, these findings suggest that age, level of education and work experience area negatively related with both KMC and MCA, this finding has important implication for the development of theory regarding the relationship between employee characteristics and strategic capabilities. This should be done through further studies

\section{References}

i. Barney, J. B. (2014). Gaining and sustaining competitive advantage. Pearson Higher Ed.

ii. Chakravarty, A., Grewal, R., \& Sambamurthy, V. (2013). Information technology competencies, organizational agility, and firm performance: Enabling and facilitating roles. Information Systems Research, 24(4), 976-997.

iii. Kamhawi, E.M. (2012). Knowledge management fishbone: a standard framework of organizational enablers. Journal of Knowledge Management, 16 (5), 808-828.

iv. Kamukama, N. (2013). Intellectual capital: company's invisible source of competitive advantage. Competitiveness Review: An International Business Journal, 23(3), 260-283.

v. Kamukama, N., Ahiauzu, A., \& Ntayi, J. M. (2011). Competitive Advantage: Mediator of Intellectual Capital and Performance. Journal of Intellectual Capital, 12 (1), 152 - 164.

vi. Liao, C., Chuang, S. H., \& To, P. L. (2011). How knowledge management mediates the relationship between environment and organizational structure. Journal of business research, 64(7), 728-736.

vii. Liu, H., Song, D., \& Cai, Z. (2014). Knowledge Management Capability and Firm Performance: The Mediating Role of Organizational Agility. In PACIS (p. 165).

viii. Mithas, S., Ramasubbu, N., \& Sambamurthy, V. (2011). How information management capability influences firm performance. MIS quarterly, 237-256.

ix. Overby, E., Bharadwaj, A., \& Sambamurthy, V. (2006). Enterprise agility and the enabling role of information technology. European Journal of Information Systems, 15(2), 120-131.

x. Sambamurthy, V., Bharadwaj, A., \& Grover, V. (2003). Shaping agility through digital options: Re-conceptualizing the role of information technology in contemporary firms. MIS quarterly, 237-263.

xi. Senaji, T., \& Nyaboga, A. B. (2011). Knowledge management process capability: operations strategy perspective. International Journal of Management and Information Systems, 15(3), 147.

xii. Senaji, T. A. (2012). Knowledge Management Infrastructure Capability, Motivation and Organisational Effectiveness among Mobile Telecommunication firms in Kenya. PhD Thesis. Kenya Methodist University

xiii. Trinh-Phuong, T., Molla, A., \& Peszynski, K. (2012). Enterprise Systems and Organizational Agility: A Review of the Literature and Conceptual Framework. Communications of the Association for Information Systems, 31. Senaji, T. A. (2012). Knowledge Management Infrastructure Capability, Motivation and Organisational Effectiveness among Mobile Telecommunication firms in Kenya. PhD Thesis. Kenya Methodist University 